\title{
Geodetic Measurement of Deformation East of the \\ San Andreas Fault in Central California
}

JEANNE M. SAUBER, MICHAEL LISOWSKI, and SEAN C. SOLOMON

(ADSA-CR-1E27(9) GECDETIC MELSUEEUENT OF DEFOERATICN EAST CP TEE SAN AREEAS FAOLT IN CENTREL CALIFCENI (Eassachesetts Inst. of $I \in C b) \quad .39 \mathrm{~F}$

$$
\begin{gathered}
\text { NAG } 5-814 \\
1 N-46-C R \\
135335 \\
39 P
\end{gathered}
$$

\section{APPENDIX 7}

$\begin{array}{ll}\text { Unclas } \\ 63 / 46 & 0135385\end{array}$




\begin{abstract}
Triangulation and trilateration data from two geodetic networks located between the western edge of the Great Valley and the San Andreas fault have been used to calculate shear strain rates in the Diablo Range and to estimate the slip rate along the Calaveras and Paicines faults in central California. Within the Diablo Range the average shear strain rate was determined for the time period between 1962 and 1982 to be $0.15 \pm 0.08 \mu \mathrm{rad} / \mathrm{yr}$, with the orientation of the most compressive strain at $N 16^{\circ} \mathrm{E} \pm 14^{\circ}$. The orientation of the principal compressive strain predicted from the azimuth of the major structures in the region is $\mathrm{N} 25^{\circ} \mathrm{E}$. We infer that the measured strain is due to compression across the folds of this area; the average shear straining corresponds to a relative shortening rate of $4.5 \pm 2.4$ $\mathrm{mm} / \mathrm{yr}$. From an examination of wellbore breakout orientations and the azimuths of P-axes from earthquake focal mechanisms the inferred orientation of maximum compressive stress was found to be similar to the direction of maximum compressive strain implied by the trend of local fold structures. Our results do not support the hypothesis of uniform faultnormal compression within the Coast Ranges. From trilateration measurements made between 1972 and 1987 on lines that are within $10 \mathrm{~km}$ of the San Andreas fault, a slip rate of 10-12 mm/yr was calculated for the Calaveras-Paicines fault south of Hollister. The slip rate on the Paicines fault decreases to $4 \mathrm{~mm} / \mathrm{yr}$ near Bitter.
\end{abstract}




\section{Introduction}

Although most of the relative motion between the Pacific and North American plates in central California is accommodated by slip along the San Andreas fault, distributed compression and right-lateral strike-slip motion on faults subparallel to the San Andreas fault also occur between the western edge of the Great Valley and the continental escarpment [Gawthrop, 1977; Page, 1981; Crouch et al., 1984; Minster and Jordan, 1984, 1987; Eaton, 1984; Namson and Davis, 1987]. Compression across the Coast Ranges is thought to be oriented nearly perpendicular to the trend of the San Andreas fault and has been proposed to result from a combination of slightly convergent relative motion between the Pacific and North American plates and low shear strength along the San Andreas fault [Zoback et al., 1987]. The majority of recent earthquakes in the Coast Ranges occur on the San Andreas fault (Figure 1). There is moderate, diffuse activity in the Diablo Range, located between the Great Valley and the San Andreas fault. The May 1983 occurrence of a large earthquake $\left(M_{S}=6.7\right)$ beneath a young fold [Stein and King, 1984; Stein, 1985] near Coalinga, California, has focused attention on the importance of understanding the rate of deformation to the east of the San Andreas fault in this region and its relation to the overall deformation in the Coast Ranges. In this paper we determine rates of deformation in the Diablo Range north of Coalinga from a triangulation and trilateration network and from line-length changes determined from short-range trilateration measurements within 10 $\mathrm{km}$ of the San Andreas fault. The geodetic data are used to place bounds on the rate of deformation across the Diablo Range and to estimate the rate of slip on the Calaveras and Paicines faults. These geodetic results are then compared with other geological and geophysical data from the Coast Ranges . 


\section{Tectonic Setting}

In this section we give an overview of the tectonics of the central Coast Ranges. The rate and orientation of slip along the San Andreas fault, as well as the magnitude of shear stress in the fault zone, have been hypothesized to influence deformation throughout the Coast Ranges. We first summarize results from geologic and geodetic studies on the segment of the San Andreas fault between Hollister and Coalinga. We then describe the geological setting and seismicity of the study region. For comparative purposes, we also discuss deformation to the west of the San Andreas fault in central California.

To characterize horizontal deformation across the San Andreas fault in central California, data from near-fault alinement arrays, creepmeters, and trilateration measurements at short and intermediate distances have been utilized [Savage and Burford, 1973; Thatcher, 1979b; Burford and Harsh, 1980; Lisowski and Prescott, 1981]. On the northwestern segment (from the latitude of Hollister south to Hepsedam, Figure 2), the rate of surface slip (creep) across the San Andreas fault increases from $\sim 13$ to $32 \mathrm{~mm} / \mathrm{yr}$ and surface slip on the Calaveras-Paicines fault decreases from $\sim 17$ to $0 \mathrm{~mm} / \mathrm{yr}$. On the central section (from Hepsedam southward to the latitude of Coalinga, Figure 2), near-fault and intermediate-scale geodetic measurements of right-lateral slip are in good agreement suggesting creep at a rate of approximately $32 \mathrm{~mm} / \mathrm{yr}$. The rate of slip on the central segment of the San Andreas fault estimated from Holocene geological data is $34 \pm 3 \mathrm{~mm} / \mathrm{yr}$ at an azimuth of $\mathrm{N} 41^{\circ} \mathrm{W} \pm 2^{\circ}$ [Sieh and Jahns, 1984; Minster and Jordan, 1984]. Southeast of the latitude of Coalinga, shallow slip on the San Andreas fault decreases and the width of the zone of deformation increases with the transition to a locked segment of the San Andreas fault in the Carrizo Plain.

The principal structural features of the Diablo Range northeast of the San Andreas fault between Hollister and Coalinga are shown in Figure 3, [modified from Dibblee, 1979]. Within 5-10 km of the San Andreas fault the primary geologic structures are related to dextral shear on the San Andreas and Calaveras-Paicines faults. The Diablo Range to the 
east of this region is a broad antiform which trends approximately $\mathrm{N} 65^{\circ} \mathrm{W}$ and encompasses subsidiary fold structures such as the Vallecitos Syncline [Page, 1985]. North of Coalinga the range is pierced by the New Idria diapir of serpentine and Franciscan rocks. Along the northeast boundary of the study area is the Ortigalita fault, a high-angle fault along or near the contact of Franciscan rocks and the Great Valley sequence to the east [Raymond, 1973]. Trenching of the Ortigalita fault zone shows exposed offsets of late Pleistocene and Holocene soils, with possibly as much as $5 \mathrm{~km}$ of Quaternary right-slip displacement [Hart et al., 1986]. The most recent uplift of the Diablo Range began in Pliocene time and most likely accelerated in the Pleistocene [Page, 1981; Page and Engebretson, 1984].

Eight focal mechanisms from the Diablo Range compiled by Eaton [1985] show a mixture of thrust, reverse, and strike-slip faulting. The location of three of the larger earthquakes with well-determined focal mechanisms, the October 1982 Idria event $\left(\mathrm{M}_{\mathrm{L}}=5.5\right)$, the May 1983 Coalinga event $\left(\mathrm{M}_{\mathrm{L}}=6.7\right)$, and the August 1985 North Kettleman Hills event $\left(M_{L}=5.5\right)$, are given in Figure 1. The focal mechanism determined for the Idria earthquake indicates thrust faulting on a plane oriented $\mathrm{N} 72^{\circ} \mathrm{E}$ or reverse slip on a plane oriented N64 $4^{\circ} \mathrm{W}$ [Eaton, 1985]. The Coalinga and Kettleman Hills events have similar focal mechanisms with slip occurring on fault planes oriented at about $\mathrm{N} 53^{\circ} \mathrm{W}$ as either thrusting on a plane dipping shallowly to the southwest or reverse slip on a plane steeply dipping to the northeast [Eaton, 1985; J.P.Eaton, personal communication, 1987]. The earthquake focal mechanisms and geological structures in the area suggest two primary modes of deformation to the northeast of the San Andreas fault; compression normal to the major fold structures of the region and right-lateral strike-slip motion on faults such as the Calaveras-Paicines and the Ortigalita.

In the central Coast Ranges to the west of the San Andreas fault focal mechanism studies of the Coast Ranges [Gawthrop, 1977; Eaton, 1984; Dehlinger and Bolt, 1987], along with extensive geologic mapping [summarized in Crouch et al., 1984; Slemmons, 
1987], suggest variable modes of deformation. Between the San Andreas and the Rinconada fault (Figure 1) is the seismically quiescent Salinian block. The upper crust is composed of high-strength granite which is only weakly folded and sparsely faulted [Dehlinger and Bolt, 1987; Slemmons, 1987]. Focal mechanisms from the Rinconada fault show a mixture of right-lateral shear faulting on northwest striking planes, oblique slip, and reverse faulting [Gawthrop, 1977; Dehlinger and Bolt, 1987]. From field mapping of recent offsets, D.B. Slemmons (personal communication, 1987) and E.W. Hart (personal communication, 1988) suggests that right-lateral strike-slip faulting is the major component of displacement along the Rinconada fault. Between the Rinconada and the San GregorioHosgri faults (Figure 1) is the Coastal Belt province. The upper crust consists of the very heterogeneous Franciscan complex. Focal mechanisms from this region indicate dominantly oblique reverse faulting along northwest-trending, northeast dipping planes, with P-axes oriented $\mathrm{N} 20^{\circ}-50^{\circ} \mathrm{E}$ or $\mathrm{S} 20^{\circ}-50^{\circ} \mathrm{W}$ [Dehlinger and Bolt, 1987]. The San Gregorio-Hosgri fault system extends from the junction of the San Gregorio and San Andreas faults near San Francisco to northwest of the Western Transverse Ranges (Figure 1). Significant late-Quaternary right-lateral strike-slip offsets have been measured on the San Gregorio fault [Clark et al., 1984]. South of Monterey Bay this fault branches into several splays with some branches showing primarily right-lateral strike-slip displacement and others showing east-up reverse faulting [Hamilton, 1987]. Focal mechanisms from the San Gregorio-Hosgri fault indicate right-lateral strike-slip faulting and oblique reverse faulting with a right-lateral component on a northeast dipping plane [Gawthrop, 1977; Eaton, 1984; Dehlinger and Bolt, 1987]. 


\section{Geodetic Strain Rates}

We make use of two geodetic networks to estimate current rates of deformation to the east of the San Andreas fault in central California. The San Benito triangulation and trilateration network spans the Paicines fault zone just east of the San Andreas fault and then extends $50 \mathrm{~km}$ in a southeast-northwest direction across the Diablo Range (Figure 2). For interstation visibility, triangulation and trilateration stations are situated on the highest points in a region; thus, many of the stations in the San Benito network are located near anticlinal peaks (Figure 3). The San Benito network is geographically well-suited for measurement of rates of deformation between the Great Valley and the Calaveras-Paicines fault. To examine more localized deformation within the zone $10 \mathrm{~km}$ to the east of the San Andreas fault, short and intermediate range lines from the U.S. Geological Survey (USGS) Coalinga trilateration network were utilized. The geodetic results derived from the Coalinga trilateration data provide an update to the slip rates estimated for the Calaveras and Paicines faults by Lisowski and Prescott [1981]. To distinguish between engineering and tensor shear strain, we denote the former by $\gamma$ and quote the units as $\mu \mathrm{rad}$, whereas the latter is denoted by $\varepsilon$ and is given in units of $\mu$ strain [Savage , 1983]. Uncertainities in all cases are one standard deviation $(\sigma)$.

\section{San Benito Network}

A triangulation survey of the San Benito network was conducted in 1962 by the National Geodetic Survey. Seventy of the seventy-two directions utilized in this study were second-order observations (a priori uncertainity is estimated to be $\sigma_{d}=0.7 "$, Federal Geodetic Control Committee, 1984) and two were third order $\left(\sigma_{d}=1.2^{\prime \prime}\right)$. An angle measurement is the difference of two direction measurements. The expected uncertainity in a second order angle measurement $\left(\sigma_{a}\right)$ is $2 \sqrt{\sigma_{d}}$; or about $1.0^{\prime \prime}$. The order of the triangulation denotes the measurement precision, which is determined by survey procedures and is reflected in the degree to which internal checks of the data are satisfied 
[Thatcher, 1979a]. The principal internal check is the triangle closure requirement that the angles of each triangle sum to $180^{\circ}$ plus the known excess due to the Earth's sphericity. Triangle closures indicate that the standard deviation of a single angle is approximately 1.1" for these data, very close to the expected value.

In 1982 a trilateration survey of the San Benito network was performed by the USGS. Regional trilateration measurements made by the USGS on line lengths of $10-40 \mathrm{~km}$ have a precision of approximately $0.2-0.3 \mathrm{ppm}$ [Savage and Prescott, 1973]. Angles observed in the 1962 survey were compared with angles that would have been measured in 1982. Azimuths for each station to station pair for the 1982 trilateration survey were determined with a variation of coordinates adjustment [Anderson, 1969].

From the changes in angles between the 1962 and 1982 surveys we calculate the horizontal shear strain rate components $\dot{\gamma}_{1}$ and $\dot{\gamma}_{2}$. In terms of the strain rate tensor, $\dot{\varepsilon}_{\mathrm{ij}}$, $\dot{\gamma}_{1}=\dot{\varepsilon}_{11}-\dot{\varepsilon}_{22}$ and $\dot{\gamma}_{2}=\dot{\varepsilon}_{12}+\dot{\varepsilon}_{21}$, where the strain rate tensor is referred to a geographic coordinate system in which the 1-axis is directed east and the the 2-axis is directed north. The strain component $\gamma_{2}$ is equal to the decrease induced by strain in the right angle between northward- and eastward-directed lines, whereas $\gamma_{1}$ is equal to the increase in the angle between lines directed northwest and northeast. Thus, $\gamma_{1}$ measures the rate of rightlateral shear across a vertical plane striking $\mathrm{N}^{\circ} 5^{\circ} \mathrm{W}$ (or the rate of left-lateral shear across a vertical plane striking $\mathrm{N} 45^{\circ} \mathrm{E}$ ) and $\gamma_{2}$ measures the rate of right-lateral shear across a vertical plane striking eastward (or the rate of left-lateral shear across a vertical plane striking northward). Angle changes between the 1962 and 1982 surveys were used to obtain the two shear strain rate components $\left(\dot{\gamma}_{1}\right.$ and $\left.\dot{\gamma}_{2}\right)$ or, equivalently the maximum shear strain rate $\left(\dot{\gamma}\right.$, where $\left.\dot{\gamma}^{2}=\dot{\gamma}_{1}^{2}+\dot{\gamma}_{2}^{2}\right)$ and the orientation of the vertical plane with maximum right-lateral shear $(\psi)$ [Frank, 1966; Prescott, 1976; Sauber et al., 1986]. For comparison with the fold structures of the Diablo Range, the orientation of the maximum compressive strain $(\beta)$ is sometimes given instead of the orientation of maximum rightlateral shear $(\psi)$. 
The angle changes associated with the stations Bitter, Hepsedam, and Panoche were significantly larger than angle changes from other portions of the network and were, therefore, examined separately. Bitter and Hepsedam are located near the Paicines fault zone. Using the 11 angle measurements that include either of the stations Bitter or Hepsedam $\dot{\gamma}=0.56 \pm 0.16 \mu \mathrm{rad} / \mathrm{yr}$ and $\Psi=\mathrm{N} 28^{\circ} \mathrm{W} \pm 11^{\circ}$. The shear strain rate across the approximately $10 \mathrm{~km}$-wide zone northeast of stations Bitter and Hepsedam, assuming right-lateral motion on the Paicines fault, implies a rate of slip of $5 \pm 2 \mathrm{~mm} / \mathrm{yr}$. Additional geodetic data from the Coalinga trilateration network relating to deformation across the San Andreas and Calaveras-Paicines faults is discussed in the next section. The relatively large angle changes around station Panoche are not so easily explained. The 7 angle changes that included Panoche $\dot{\gamma}=0.76 \pm 0.27 \mu \mathrm{rad} / \mathrm{yr}, \psi=\mathrm{N} 58^{\circ} \mathrm{W} \pm 9^{\circ}$ or $\beta=\mathrm{N} 13^{\circ} \mathrm{W} \pm 9^{\circ}$. These results are not consistent with either shear strain across the Ortigalita fault zone or contraction across the major fold structures of the region. We suspect a survey blunder, but the sparse measurements in this part of the network do not provide sufficient redundancy to identify such errors. Because the strain accummulation in this part of the network was significantly different than the strain estimated from other portions of the network, angles which included the station Panoche were omitted from further analyses. Results from the northern portion of the network which would be sensitive to slip on the Ortigalita fault are unfortunately weakened by this omission.

The strain rate parameters estimated on the basis of 25 angle changes in the central portion of the San Benito network, excluding angles to Bitter, Hepsedam or Panoche, were $\dot{\gamma}=0.15 \pm 0.08 \mu \mathrm{rad} / \mathrm{yr}, \beta=\mathrm{N} 16^{\circ} \mathrm{E} \pm 14^{\circ}$ or $\psi=\mathrm{N} 29^{\circ} \mathrm{W} \pm 14^{\circ}$. The standard deviations reflect both misfit and data uncertainities due to measurement imprecision. Although there is no significant strain at the $95 \%$ confidence limit, the orientation of the principal strain directions are consistent with the geological structures of the region. The azimuth of the least compressive strain $\left(\mathrm{N} 74^{\circ} \mathrm{W} \pm 14^{\circ}\right)$ is close to the trend of the major fold structures of 
the region $\left(\mathrm{N} 65^{\circ} \mathrm{W}\right)$. The shear is also close to the trend of the major strike-slip faults of the region.

To search for significant strain inhomogeneity, the shear strain parameters were estimated from spatial subsets of these data, again excluding the Bitter, Hepsedam, and Panoche stations (Table 1). There is a trade-off between improving the precision of the strain estimate by using a large number of angles and averaging spatial variations as the size of the sampled region is increased. In the first case, the data were broken into two distinct groups, one set closer to the Great Valley ("east") and one set closer to the San Andreas fault ("west"). If the measured rate of shear strain were due to strain accumulation on the adjacent San Andreas fault, the predicted rate of shear strain would be higher in the west subnet. Alternatively, if the rate of compressive strain was higher across the folds near the Great Valley, the east subnet might show a higher shear strain rate. There is no suggestion of a significant rate difference between the strain rates determined from the east and west data subgroups. The set of 25 angles were also divided into "north" and "south" sets to look for any change which might be associated with along-strike variations on the San Andreas and Calaveras-Paicines faults. Although the strain results differ in the subnets, particularly in the orientation of maximum compression, the rate and orientation of strain in the various subregions are not significantly different than the average value determined from the complete set of 25 angles.

If we assume that the strain perpendicular to the fold structures is homogeneous across the region between the western edge of the Great Valley and the western extent of the San Benito network (average width of $30 \mathrm{~km}$ ) and that there is no extension parallel to the fold structures, the average strain rate corresponds to $4.5 \pm 2.4 \mathrm{~mm} / \mathrm{yr}$ of shortening. From a geological reconstruction of the structures between the Great Valley and the San Andreas fault at the approximate latitude of Coalinga , Namson and Davis [1987] have inferred that $11 \mathrm{~km}$ of late Cenozoic shortening has occurred perpendicular to the San Andreas fault. This quantity can be used to estimate an average rate of shortening perpendicular to the San 
Andreas fault. If active folding commenced $5 \mathrm{~m} . \mathrm{y}$. ago, the average rate of shortening has been $2.2 \mathrm{~mm} / \mathrm{yr}$. If folding began as recently as $2 \mathrm{~m}$.y ago an average rate of shortening of $5.5 \mathrm{~mm} / \mathrm{yr}$ is required.

A future trilateration or GPS survey could provide a more precise estimate of crustal deformation across the Diablo Range and may give the resolution necessary to discern spatial variations in the deformation field. Additionally instead of determining only the shear strain parameters $\left(\dot{\gamma}_{1}\right.$ and $\left.\dot{\gamma}_{2}\right)$ all the components of the rate of tensor strain $\left(\dot{\varepsilon}_{\mathrm{ij}}\right)$ could be estimated. Using all the stations in the San Benito network an additional trilateration survey in 1987 would have provided $\sim 0.034 \mu$ strain/yr accuracy in the principal strains.

\section{Coalinga Trilateration Network}

We have employed short and intermediate-length lines from the Coalinga trilateration network to update previous estimates [Lisowski and Prescott, 1981] of the slip rates on the Calaveras and Paicines faults (Figure 2). Trilateration measurements are made periodically by the USGS in central California on a regional scale spanning a 20-km-wide zone centered on the San Andreas fault and including several distinct faults, as well as on smaller (1-2 $\mathrm{km}$ ) aperture networks that span a single fault (Pionne, Dry Lake and Tully nets). The estimated accuracy in the line lengths determined from the short-range measurements is equal to $4 \mathrm{~mm}$ [Lisowski and Prescott, 1981].

For the region within $10 \mathrm{~km}$ to the east of the San Andreas fault we assume that the deformation is right-lateral shear across the Calaveras-Paicines fault system. Strike-slip type motion across these faults would shorten north-south lines and extend east-west lines, whereas contraction across structures such as the Paicines syncline would shorten northeast-southwest lines. Line length changes in the Pionne short-range network and the lines from Bitter to Hepsedam and Brown to Cross are consistent with the hypothesis of right-lateral slip on the Calaveras-Paicines fault system. 
If the deformation in this region occurs as rigid block motion along the CalaverasPaicines fault system, the observed length changes can be converted into a fault-parallel displacement rate from the slope of the least-squares linear fit to the interstation length data [Prescott and Lisowski, 1983]. The slip rates determined from lines crossing the fault at a low angle are given in Table 2 for the Calaveras-Paicines region just south of Hollister and for the Paicines fault zone between Bitter and Coalinga. The slip rate determined from the station pairs that cross only the San Andreas fault (Cross/Chalone and Chalone/Bitter lines) plus the slip rate from pairs that are completely east of the San Andreas fault (Browns/Cross and Bitter/Hepsedam) are shown to be approximately equal to the slip rate from station pairs that span both fault zones (Brown/Chalone and Chalone/Hepsedam lines). The line length changes across the Calaveras-Paicines fault zone are consistent with $\sim 10 \mathrm{~mm} / \mathrm{yr}$ of right-lateral slip. For the Paicines fault further south a lower rate of 3-4 $\mathrm{mm} / \mathrm{yr}$ of slip is indicated. For comparison, the late Quaternary slip rate estimated on the Paicines fault estimated from an offset terrace riser and an offset hill $\sim 10 \mathrm{~km}$ south of Hollister is $3.5-13 \mathrm{~mm} / \mathrm{yr}$ [Harms et al., 1987].

Some of the lines in the Coalinga network showed a significant change in slope beginning in mid-1978. This change corresponded to an increase in the rate of slip on the Calaveras-Paicines system and a decrease in slip rate on the San Andreas fault. A similar change after 1979 in the inferred slip rates for the Calaveras and San Andreas faults was reported from geodetic measurements from the Hollister trilateration network [G. Gu and J. C. Savage, personal communication, 1986; Matsu'ura et al., 1986]. The increase in slip on the Calaveras fault approximately coincided with the occurrence of the 1979 Coyote Lake earthquake $\left(M_{L}=5.7\right)$ on the northern Calaveras fault .

The average fault slip indicated by the three short-range networks (Figure 2), again assuming simple block motion, is given in Table 3. The rate of slip on the Pionne net, 12 $\pm 2 \mathrm{~mm} / \mathrm{yr}$, is similar to the rate estimated from the line between Cross and Brown which crosses the Calaveras-Paicines fault zone $(10 \pm 1 \mathrm{~mm} / \mathrm{yr})$. Between the Dry Lake and Tully 
networks the rate of creep on the San Andreas fault increases from 27 to $32 \mathrm{~mm} / \mathrm{yr}$. South of the Tully network the rate of slip determined from near-fault data is the same on the San Andreas fault as the rate estimated from the longer trilateration lines. The short and intermediate range trilateration measurements document a transfer of slip associated with the Calaveras-Paicines fault zone to the San Andreas fault. The narrowing of the region that accommodates the $\sim 32 \mathrm{~mm} / \mathrm{yr}$ slip rate also corresponds to a transition from a complex multi-stranded portion of the fault system with locked segments that break in periodic moderate to large earthquakes to a geometrically simpler segment that accommodates slip through creep.

\section{Comparison of Geodetic Strain Directions with Principal Stress Directions and Orientations of Geological Structures}

In this section we compare the geodetically determined incremental strain directions to the orientation of the maximum principal stress $\left(\sigma_{1}\right)$ estimated from wellbore breakouts and the azimuths of $\mathrm{P}$-axes determined from earthquake focal mechanisms. The orientations of principal stress directions determined from breakout orientations, earthquake fault plane solutions, and the azimuths of major fold structures in central California have been used to infer the state of stress on and near the San Andreas fault and to distinguish between models relating the formation of fold structures in the Coast Ranges to motion along the San Andreas fault [Zoback et al., 1987; Mount and Suppe, 1987; Namson and Davis, 1988].

Due to extensive drilling for oil east of the San Andreas fault, a large number of wells have been available for measurement of stress-induced wellbore breakout orientations. Borehole breakouts are caused by unequal stress concentrations around a borehole wall and create elongations of the hole in directions perpendicular to the orientation of the maximum horizontal stress [Springer, 1987]. Breakouts are generally oriented northwest-southeast, indicating a northeast-southwest orientation for the compressive stress, a direction 
perpendicular to the major fold axes near the San Joaquin Valley and at a $70^{\circ}-90^{\circ}$ angle to the San Andreas fault [Springer, 1987; Zoback et al., 1987; Mount and Suppe, 1987]. To the east of the San Andreas fault the majority of breakout measurements have been made in wells near the western edge of the San Joaquin Valley (Figure 4); comparatively fewer wellbore breakout orientations have been obtained closer to the San Andreas fault within the area of the geodetic measurements reported in this paper.

The orientation of maximum principal stress may also be inferred from welldetermined fault plane mechanisms, notably from the 1982 Idria, the 1983 Coalinga, and the 1985 North Kettleman Hills earthquakes (Figure 4). For the Coalinga and the North Kettlman Hills events the P-axis orientation is $\sim \mathrm{N} 37^{\circ} \mathrm{E}$ [Eaton, 1985; J.P. Eaton, personal communication, 1987], similar to the $\sigma_{1}$ directions inferred from breakout orientations in the same region. The azimuth of the $\mathrm{P}$ axis for the Idria event is $\mathrm{N} 12^{\circ} \mathrm{E}$ [Eaton, 1985].

As may be seen in Figure 4, the breakout orientations and the P-axis directions are very similar to the orientation of maximum compressive strain implied by the trend of local fold structures. Along the western edge of the Great Valley and near Coalinga, the direction of $\sigma_{1}$ inferred from the breakout orientations and two earthquake focal mechanisms and the orientation of maximum compressive strain inferred from the fold trends, is $\mathrm{N} 30-50^{\circ} \mathrm{E}$. To the northwest of Coalinga, including the region spanned by the San Benito network, the direction of maximum compressive strain estimated geodetically and the orientation predicted from the azimuth of the local fold structures and the $\sigma_{1}$ direction inferred from one wellbore breakout orientation and the P-axis orientation of the Idria earthquake is N12-25 $\mathrm{E}$. Mount and Suppe [1987] suggest that the folds in this area have been inactive since the Miocene; the rate of deformation determined for the region spanned by the San Benito network suggests, however, that ongoing compressive strain is being accommodated across these folds. Within $5 \mathrm{~km}$ of the San Andreas fault, the $\sigma_{1}$ direction inferred from one wellbore breakout orientation and the direction of maximum compressive strain inferred from azimuths of folds is $\mathrm{N} 30^{\circ}-60^{\circ} \mathrm{E}$. 
Mount and Suppe [1987] and Zoback et al. [1987] have used contempory in situ tectonic stress indicators near the San Andreas fault system in central California to show that the direction of maximum horizontal compression is nearly perpendicular to the San Andreas fault. The observation of uniform fault-normal compression in a $50-100 \mathrm{~km}$ wide zone spanning the San Andreas fault has been cited as evidence for low shear stress on the San Andreas fault and a decoupling of off-fault normal compression and transcurrent deformation [Mount and Suppe, 1987]. The principle stress directions inferred from focal mechanisms and breakout orientations, particularly at distances greater than $30 \mathrm{~km}$ from the San Andreas fault, support the observation of fault normal compression in portions of the Coast Ranges. Our results suggest examination in detail of principal stress and strain orientations within the Diablo Range do not support the hypothesis of uniform fault-normal compression in central California.

There are several factors which may complicate the interpretation of measurements used distinguish between models relating the formation of fold structures in the Coast Ranges to motion along the San Andreas fault . Firstly, there may be processes that act on different length scales which might explain the change in the $\sigma_{1}$ direction and the trend of fold structures at different distances from the San Andreas fault. For example, within a narrow zone centered on the San Andreas fault, local geological structures may be due to geometrical complexities in the fault trace [Segall and Pollard, 1980] or the rheological structure of the fault zone [Horns et al., 1985]. Also, the local stress field orientation may differ from the regional stress field due to material heterogeniety. Finally, as will be discussed in the next section, there is the additional complexity that deformation in the Coast Ranges is related, in the kinematic sense, to the overall deformation across the Pacific-North American plate boundary. 


\section{Relation of Deformation East of the San Andreas Fault to the Overall Deformation in the Coast Ranges}

In this section we examine the rates and sense of deformation estimated for different subregions of the Coast Ranges, and we discuss the relation of these results to the accommodation of Pacific-North American plate motion as constrained by global plate models and other regional studies. Finally we briefly suggest future geodetic studies which may provide additional constraints on the rate of deformation in the Coast Ranges.

Global plate models, which yield the relative motion between the North American and Pacific plates, have been used as kinematic boundary conditions on the integrated deformation across the plate boundary zone in the Western United States [Minster and Jordan, 1984, 1987; Bird and Rosenstock, 1984; Weldon and Humphreys, 1986]. If the San Andreas fault functioned as a simple boundary that accommodated the full motion between two rigid plates, the predicted rate of slip in central California would be $\sim 49$ $\mathrm{mm} / \mathrm{yr}$ at $\sim \mathrm{N} 35^{\circ} \mathrm{W}$ [DeMets et al., 1987]. Deformation across the Pacific-North American boundary is instead thought to be distributed across a broad zone between the continental escarpment and the eastern front of the Basin and Range province. As summarized above, the rate of slip on the San Andreas fault in central California oriented at $N 41^{\circ} \mathrm{W} \pm 2^{\circ}$ is constrained from Holocene geological data and ground-based geodetic measurements to be $34 \pm 3 \mathrm{~mm} / \mathrm{yr}$. The vector difference between the plate motion and the San Andreas rate is $\sim 16 \mathrm{~mm} / \mathrm{yr}$ in the direction $\mathrm{N} 21^{\circ} \mathrm{W}$. The integrated rate of deformation to the east of the San Andreas fault across the Basin and Range has been estimated from geological observations averaged over the Holocene and from Very Long Baseline Interferometry (VLBI) to be $9.7 \pm 2.1 \mathrm{~mm} / \mathrm{yr}$ at $\mathrm{N} 56^{\circ} \mathrm{W} \pm 10^{\circ}$ [Minster and Jordan, 1987]. The vector difference derived using the above rates of motion for the San Andreas fault and Basin and Range, referred to as the discrepancy vector [Minster and Jordan, 1987], is $\sim 10 \mathrm{~mm} / \mathrm{yr}$ in the direction $N 14^{\circ} \mathrm{E}$ or $\sim 5 \mathrm{~mm} / \mathrm{yr}$ parallel to the San Andreas fault and $\sim 8 \mathrm{~mm} / \mathrm{yr}$ of convergence normal to the fault. On the basis of estimations made by Minster and Jordan 
[1987], the uncertainities in the discrepancy vector are approximatelly $\pm 5 \mathrm{~mm} / \mathrm{yr}$ for the rate of slip and $\pm 15^{\circ}$ in the direction. Although some minor internal deformation within the Sierra Nevada block [Lockwood and Moore, 1979] or across the Great Valley syncline may occur, most of the deformation represented by the discrepancy vector is thought to occur within the Coast Ranges.

A compilatation of rates of deformation in the Coast Ranges, separated into estimated rates of right-lateral strike-slip motion on specific faults and rates of distributed compression, is given in Table 4. In general the geological data are most useful for placing upper and lower bounds on rates and for indicating long-term modes of deformation. The large range in most geologically determined rate estimates are due to uncertainities in dating rock units and in the interpretation of geological reconstructions. To extrapolate incremental strain rates determined over a geologically short interval to infer long-term slip rates requires that the measured process accumulates strain in a temporally uniform manner. Temporal variations in the rate of strain accumulation, however, have been documented to occur during and after large earthquakes [Thatcher, 1986], and there is a suggestion that the rate of slip on the Paicines and Calaveras faults changed at about the time of the 1979 Coyote Lake earthquake (see earlier section). An additional complexity involved in using geodetic data is that the measured strain rate may be due to the superposition of more than one ongoing geologic process. This case is illustrated by geodetic data from the USGS San Luis network located near Parkfield, California (Figure 5). Within the area spanned by the San Luis network, geological studies suggest two primary modes of neotectonic deformation (see discussion of deformation west of the San Andreas fault in the Tectonic Setting section). The San Andreas fault in this region ruptures in periodic moderate earthquakes on approximately 22-year intervals [Bakun and McEvilly, 1984]; the last earthquake occurred in 1966. During the interseismic period, right-lateral shear strain at the orientation of the San Andreas fault accumulates. To the west of the San Andreas fault, northeast-southwest compression is thought to occur within the Coastal Belt province. 
When subregions of the San Luis network within the Coastal Belt province were examined the rate of strain was found to be right-lateral shear strain at the orientation of the San Andreas fault [King et al., 1986]. As discussed in Table 4, Harris and Segall [1987]were only able to estimate the rate of fault-normal compression by including it as a parameter in their inversion. As discussed above, on the segment of the San Andreas fault adjacent to the San Benito network, fault slip occurs primarily through creep and we would expect little right-lateral shear strain accumulation associated with the San Andreas fault to be measured on off-fault geodetic lines. Thus we interpreted the rate of strain determined from the San Benito measurements to be associated with the fold structures of the region.

To explore the implications of the constraints provided by the San Andreas discrepancy vector we compare the predicted rates of fault-parallel and fault normal deformation to the values given in Table 4. There are several faults on which recent rightlateral strike-slip displacements have been observed. At this point we cannot distinguish between a model in which $5 \mathrm{~mm} / \mathrm{yr}$ of predicted fault-parallel motion is distributed over all the strike-slip faults in Table 4 and a model in which only the San Gregorio-Hosgri fault accommodates the predicted slip rate. The geological and seismicity data (Figure 1) suggest that northeast-southwest compression may be localized to two regions, the $30 \mathrm{~km}$ wide zone spanned by the San Benito network and within the Coastal Belt province. If shortening across the Coast Ranges was divided between these two regions, approximately $4 \mathrm{~mm} / \mathrm{yr}$ of shortening is predicted to occur within the Diablo Range. If the $8 \mathrm{~mm} / \mathrm{yr}$ is distributed uniformly across the $170 \mathrm{~km}$-wide zone between the western edge of the Great Valley and the continental escarpment, the shortening across the region spanned by the San Benito network would be approximately $1.4 \mathrm{~mm} / \mathrm{yr}$. The rate of deformation estimated from the San Benito study is most consistent with the first hypothesis; but the uncertainities in our calculated values do not allow the latter hypothesis to be ruled out.

Results from ongoing geodetic studies with stations in central California should provide additional constraints on the rate and distribution of slip within the Coast Ranges. 
The rate of slip estimated from VLBI measurements made at Vandenberg, Fort Ord, Presidio, and Point Reyes (Figure 5) could potentially be used to constrain the rate of deformation across the Coast Ranges. To distinguish between different models will require uncertainities in the rate of slip, relative to a fixed reference, of $2-3 \mathrm{~mm} / \mathrm{yr}$. Our preliminary analysis of VLBI data, based on measurements between October 1982 and March 1987, indicate that only the rate of slip at the station Vandenberg meets this requirement [Sauber et al., 1987; see also Clark et al., 1987]. Additional measurements of all of the VLBI stations in central California have been made within the last year and an analysis of these measurements will be the subject of a later paper. Rate of deformation estimated from measurements to the Farallon Islands (Figure 5) will be updated following a trilateration survey of the network by the USGS in 1988; such information should provide a better constraint on the rate of slip on the San Gregorio fault.

\section{Summary}

We have examined triangulation and trilateration data from two geodetic networks that lie within the region north of Coalinga, California, between the Great Valley and the San Andreas fault. The shear strain rate was determined to be $0.15 \pm 0.08 \mu \mathrm{rad} / \mathrm{yr}$ for the Diablo Range region. If we assume that this deformation is due to compression across the folds of this area, as is suggested by the orientation of the axis of maximum compressive strain $\left(\mathrm{N} 16^{\circ} \mathrm{E} \pm 14^{\circ}\right)$, the average shear straining corresponds to a relative shortening rate of

\section{$4.5 \pm 2.4 \mathrm{~mm} / \mathrm{yr}$.}

We compared the geodetically determined incremental principal strain direction to the orientation of maximum principal stress directions estimated from wellbore breakouts and the azimuths of $\mathrm{P}$-axes determined from earthquake focal mechanisms east of the San Andreas fault in central California. The breakout orientations and the Paxes directions within the Diablo Range and near the western edge of the Great Valley were found to be similar to the orientation of maximum compressive strain implied by the trend 
of local fold structures. Our results suggest that the principal stress and strain directions within the Diablo Range not support the hypothesis of uniform fault-normal compression proposed by Mount and Suppe [1987].

For a zone within $10 \mathrm{~km}$ of the San Andreas fault, trilateration measurements on offfault lines east of the San Andreas fault as well as lines that cross the San Andreas fault have been used to estimate the rate of slip along the Calaveras-Paicines fault and to document the gradual southward transition in the width of the zone accommodating rightlateral fault slip. South of Hollister the inferred rate of slip on the Calaveras-Paicines fault was found to be $10-12 \mathrm{~mm} / \mathrm{yr}$. The rate of slip on the Paicines fault near Bitter is $\sim 4$ $\mathrm{mm} / \mathrm{yr}$. Further south all the slip (at least across the $\sim 20 \mathrm{~km}$ wide zone of measurements) occurs on the San Andreas fault.

Acknowledgements. We thank Wayne Thatcher, Jerry Eaton, Will Prescott, and James Savage for assistance while the first author was in Menlo Park, Richard Snay for the triangulation direction lists and Tom Jordan and Bernard Minster for constructive reviews. Trilateration surveys were performed by the U.S. Geological Survey's Crustal Strain Project under the direction of Will Prescott. Support for part of this research was provided by the U.S.Geological Survey while the first author was in Menlo Park. The portion of this research conducted at the Massachusetts Institute of Technology was supported by the National Aeronautics and Space Administration through a Graduate Student Research Fellowship (NGT-50103) to Jeanne Sauber and through Crustal Dynamics Project grant NAG5-814. 


\section{References}

Anderson, W.L., Weighted triangulation adjustment, U.S. Geol. Surv. Open-File Rep. Computer Contribution Number 1, U.S. Geological Survey Computer Center Division, Washington, D.C., 52 pp., 1969.

Bakun, W.H., and T.V. McEvilly, Recurrence models and Parkfield, California earthquakes, J. Geophys. Res., 89, 3051-3058, 1984.

Bird, P., and R.W. Rosenstock, Kinematics of present crust and mantle flow in southern California, Geol. Soc. Am. Bull., 95, 946-957, 1984.

Burford, R.O., Strain analysis across the San Andreas fault and Coast Ranges of California, Ph.D. thesis, 74 pp., Stanford University, Stanford, California, 1967.

Burford, R.O., and P.W. Harsh, Slip on the San Andreas fault in central California from alinement array surveys, Bull. Seismol. Soc. Am., 70, 1233-1261, 1980.

Clark, M.M., K. Harms, J. Lienkaemper, D. Harwood, K. Lajoie, J. Matti, J. Perkins, M. Rymer, A. Sarna-Wojcicki, R. Sharp, J. Sims, J. Tinsley, J. Ziony, Preliminary slip-rate table and map of late quaternary faults of California, U.S. Geol. Surv. OpenFile Rep., 84-0106, 1984.

Clark, T.A., D. Gordon, W.E. Himwich, C. Ma, A. Mallama, and J.W. Ryan, Determination of relative site motions in the western United States using Mark III very long baseline interferometry, J. Geophys. Res., 92, 12741-12750, 1987.

Crouch, J.K., S.B. Bachman, and J.T. Shay, Post-Miocene compressional tectonics along the central California margin, in Tectonics and Sedimentation along the California Margin, edited by J.K. Crouch and S.B. Bachman, Pac. Sect. Soc. Econ. Paleontol. Mineral., 38, 37-54, 1984.

Dehlinger, P. and B.A. Bolt, Earthquakes and associated tectonics in a part of Coastal central California, Bull. Seismol. Soc. Am, 77, 2056-2073, 1987. 
DeMets, C., R.G. Gordon, S. Stein, and D.F. Argus, A revised estimate of Pacific-North American motion and implications for western North America plate boundary zone tectonics, Geophys. Res. Let., 14, 911-914,1987.

Dibblee, T.W., Regional geology of the central Diablo Range between Hollister and New Idria, in Field Trip Guidebook for the Geological Society of America Cordilleran Section Meeting, edited by T.H. Nilsen and T.W. Dibblee, pp. 6-16, 1979.

Eaton, J.P., Focal mechanisms of near-shore earthquakes between Santa Barbara and Monterey, California, U.S. Geol. Surv. Open-File Rep. 84-477, pp. 13, 1984.

Eaton, J.P., Regional seismic background of the May 2, 1983 Coalinga earthquake, in Proceedings of Workshop XXVII, Mechanics of the May 2, 1983 Coalinga Earthquake, edited by M.J. Rymer and W.L. Ellsworth, U.S. Geol. Surv. Open-File Report 85-44, pp. 44-60, 1985.

Engdahl, E.R. and W.A. Rinehart, Seismicity map of North America, continent-scale map of North America, CSM-5, Decade of North American Geology, preprint 1987.

Federal Geodetic Control Committee, Standards and specifications for geodetic control networks, NOAA, U.S. Dep. of Commer. Rockville, Md., 1984.

Frank, F.C., Deduction of earth strains from survey data, Bull. Seismol. Soc. Am., 56, $35-42,1966$.

Gawthrop, W.J., Seismicity and tectonics of the central California coastal region, M.S. thesis, University of Colorado, Boulder, 76pp., 1977.

Hamilton, D.H., Characterization of the San Gregorio-Hosgri fault system, coastal central California, Geol. Soc. Am. , Abstracts with Programs, 19, 385, 1987.

Harms, K.K., J.W. Harden and M.M. Clark, Use of quantified soil development to determine slip rates on the Paicines fault, northern California, Geol. Soc. Am. Abstracts with Programs, 19, 387, 1987.

Harris, R.A., and P.Segall, Detection of a locked zone at depth on the Parkfield, California, segment of the San Andreas fault, J. Geophys. Res., 92, 7945-7962, 1987. 
Hart, E.W., W.A. Bryant, M.W. Manson and J.E. Kahle, Summary report: Fault evaluation program 1984-1985, south Coast Ranges region and other areas, Calif. Div. Mines Geol., Open-File Report 86-3SF, 1986.

Horns, D.M., C.Y. Wang, and Y.Shi, Investigation of the uplift along the San Andreas fault zone, Eos Trans. AGU, 66, 1093, 1985.

Jennings, C.W., Fault map of California, Calif. Geol. Data Map Ser., map 1, Calif. Div. of Mines and Geol, Sacramento, 1975.

King, N.E., P. Segall, and W. Prescott, Geodetic measurements near Parkfield, California, 1959-1984, J. Geophys. Res., 92, 2747-2766, 1987.

Lisowski, M., and W.H. Prescott, Short-range distance measurements along the San Andreas fault system in central California, 1975 to 1979, Bull. Seismol Soc. Am., 71, 1607-1624, 1981.

Lockwood, J.P., and J.G. Moore, Regional deformation of the Sierra Nevada, California, on conjugate microfault sets, J. Geophys. Res., 92, 2747-2766,1987.

Matsu'ura, M., D.D. Jackson and A. Cheng, Dislocation model for aseismic crustal deformation at Hollister, California, J. Geophys. Res., 91, 12661-12674, 1986.

Minster, J.B., and T.H. Jordan, Vector constraints on Quaternary deformation of the western United States east and west of the San Andreas fault, in Tectonics and Sedimentation along the California Margin, edited by J.K. Crouch and S.B. Bachman, Pac. Sect. Soc. Econ. Paleontol. Mineral., 38, 1-16, 1984.

Minster, J.B., and T.H. Jordan, Vector constraints on western U.S. deformation from space geodesy, neotectonics, and plate motions, J. Geophys. Res., 92, 4798-4804, 1987.

Mount, V.S., and J. Suppe, State of stress near the San Andreas fault: Implication for wrench tectonics, Geology, 15, 1143-1146, 1987.

Namson, J.S., and T.L. Davis, Seismically active fold and thrust belt in the San Joaquin Valley, central California, Geol. Soc. Am. Bull., in press, 1988. 
Page, B.M., The southern Coast Ranges, in The geotectonic development of California, edited by W. G. Ernst, pp. 329-417, Prentice Hall, Englewood Cliffs, N.J., 1981.

Page, B.M., Geologic background of the Coalinga earthquake of May 2, 1983, in Proceedings of Workshop XXVII, Mechanics of the May 2, 1983 Coalinga Earthquake, edited by M.J. Rymer and W.L. Ellsworth, U.S. Geol. Surv. Open-File Report 85-44, pp. 44-60, 1985.

Page, B.M., and D.C. Engebretson, Correlation between the geologic record and computed plate motions for central California, Tectonics, 3, 133-155, 1984.

Prescott, W.H., An extension of Frank's method for obtaining crustal shear strains from survey data, Bull. Seismol. Soc. Am., 66, 1847-1853, 1976.

Prescott, W.H., and M. Lisowski, Strain accumulation along the San Andreas fault system east of San Francisco Bay, Califormia, Tectonophysics, 97, 41-56, 1983.

Prescott, W.H., and S. Yu, Geodetic measurement of horizontal deformation in the northern San Francisco Bay region, California, J. Geophys. Res., 91, 7475-7484, 1986.

Raymond, L.A., Tesla-Ortigalita fault, Coast Range thrust fault, and Franciscan metamorphism, northeastern Diablo Range, California, Geol. Soc. Am. Bull., 84, 3547-3562, 1973.

Sauber, J., W. Thatcher, and S.C. Solomon, Geodetic measurement of deformation in the central Mojave Desert, California, J. Geophys. Res., 91, 12683-12693, 1986.

Sauber, J., T.H. Jordan, G.C. Beroza, T.A. Clark, and M. Lisowski, Constraints on North American-Pacific plate boundary deformation in central California from VLBI and ground-based geodetic data, Programs and Abstracts, The Impact of VLBI on Astrophysics and Geophysics, IAU Symposium No. 129, 7.1, 1987.

Savage, J.C., Strain accumulation in western United States, Ann. Rev. Earth Planet.Sci. $11,11-43,1983$. 
Savage, J.C., and R.O. Burford, Geodetic determination of relative plate motion in central California, J. Geophys. Res., 78, 832-845, 1973.

Savage, J.C. and W.H. Prescott, Precision of Geodolite distance measurements for determining fault movements, J. Geophys. Res., 78, 6001-6008, 1973.

Segall, P., and D.D. Pollard, The mechanics of discontinuous faults, J. Geophys. Res., $85,4337-4350,1980$.

Segall, P., and R. Harris, Slip deficit on the San Andreas fault at Parkfield, California, as revealed by inversion of geodetic data, Science, 233, 1409-1413, 1986.

Sieh, K.E., and R.H. Jahns, Holocene activity of the San Andreas fault at Wallace Creek, California, Geol. Soc. Am. Bull., 95, 883-896, 1984.

Slemmons, D.B., Capable faults and tectonically active folds of the California central Coast Ranges, Geol. Soc. Am. Abstracts with Programs, 19, 452, 1987.

Springer, J.E., Stress orientations from wellbore breakouts in the Coalinga region, Tectonics, 6, 667-676, 1987.

Stein, R.S., Evidence for surface folding and subsurface fault slip from geodetic elevation changes associated with 1983 Coalinga, California earthquake, in Proceedings of Workshop XXVII, Mechanics of the May 2, 1983 Coalinga Earthquake, edited by M.J. Rymer and W.L. Ellsworth, U.S. Geol . Surv. Open-File Report 85-44, pp.44-60, 1985.

Stein, R.S., and G.C.P. King, Seismic potential revealed by surface folding: 1983 Coalinga, California, earthquake, Science, 224, 869-872, 1984.

Thatcher, W., Horizontal crustal deformation from historic geodetic measurements in southern California, J. Geophys. Res., 84, 2351-2370, 1979a.

Thatcher, W., Systematic inversion of geodetic data in central California, J. Geophys. Res., 84, 2283-2295, $1979 b$.

Thatcher, W., Geodetic measurement of active-tectonic processes, in Active Tectonics, 155-163, National Academy Press, Washington, D.C., 1986. 
Vanicek, P., and E. Krakiwsky, Geodesy: The Concepts, pp.697, Elsevier Science Publishers, New York, NY, 1986.

Weldon, R., and G. Humphreys, A kinematic model of southern California, Tectonics, 5, 33-48,1986.

Zoback, M.D., M.L. Zoback, V.S. Mount, J. Suppe, J.P. Eaton, J.H. Healy, D. Oppenheimer, P. Reasenberg, L. Jones, C.B. Rayleigh, I.G. Wong, O. Scotti, and C. Wentworth, New evidence on the state of stress of the San Andreas fault sytem, Science, 238, 1105-1111, 1987.

M. Lisowski, U.S. Geological Survey, 345 Middlefield Road, MS 977, Menlo Park, CA 94025.

J. Sauber and S.C. Solomon, Department of Earth, Atmospheric, and Planetary Sciences, Building 54-526, Massachusetts Institute of Technology, Cambridge, MA 02139. 


\section{Figure Captions}

Figure 1. Earthquakes $\left(\mathrm{M}_{\mathrm{L}} \geqslant 4.0\right)$ in the Coast Ranges from January 1962 through December 1982 [Engdahl and Rinehart, 1987]. The location of three earthquakes with well-determined focal mechanisms, the 1982 Idria, the 1983 Coalinga, and the 1985 North Kettleman Hills events are given by stars. Fault traces are simplified from Jennings [1975]: HF=Hosgri fault, $\mathrm{RF}=\mathrm{Rinconada}$ fault, $\mathrm{SAF}=$ San Andreas fault, $\mathrm{SGF}=\mathrm{San}$ Gregorio fault, WTR=Westem Transverse Ranges. SF=City ofSan Fransico, An outline of the San Benito triangulation/trilateration network is given for reference.

Figure 2. Location of stations in the San Benito triangulation/trilateration network (solid circles), the Coalinga trilateration network (open circles), and small aperture trilateration networks (triangles). Half-filled circles denote stations that were part of both the San Benito and Coalinga networks. Quaternary faults [Jennings, 1975] are also shown. \#C=city of Coalinga, California, $\# \mathrm{H}=$ city of Hollister, California. Stations discussed in the text include $\mathrm{BIT}=\mathrm{Bitter}, \mathrm{BRN}=\mathrm{Brown}, \mathrm{CHL}=\mathrm{Chalone}, \mathrm{CRS}=$ Cross, $\mathrm{HEP}=$ Hepsedam, and $\mathrm{PAN}=\mathrm{Panoche}$.

Figure 3. Major structural features of the Diablo Range between Hollister and Coalinga [modified from Dibblee, 1979]. The locations of stations in the San Benito triangulation/trilateration network are shown as circles for reference. \#C=city of Coalinga, California, \#H=city of Hollister, California, $\mathrm{CA}=$ Coalinga Anticline, $\mathrm{CFZ}=\mathrm{Calaveras}$ fault zone, $\mathrm{NI}=\mathrm{New}$ Idria diapir, $\mathrm{OFZ}=$ Ortigalita fault zone, $\mathrm{PF}=\mathrm{Paicines}$ fault, $\mathrm{PS}=\mathrm{Paicines}$ 
Syncline, VS=Vallecitos Syncline. Inward pointing double arrows indicate a syncline, outward pointing double arrows an anticline. Single arrows indicate the direction of plunge of a fold axis.

Figure 4. Fold structures and measured stress orientation in the region east of the San Andreas fault in central California [modified from Mount and Suppe, 1987]. Dashed lines indicate a syncline, a dotted line indicates an anticline. Single arrows indicate the direction of plunge of a fold axis. Wellbore breakout measurements are given by a solid line with inward pointing arrows perpendicular to the direction of $\sigma_{1}$. The direction of $\sigma_{1}$ inferred from the azimuth of $\mathrm{P}$-axis for three earthquakes are labeled 1,2,and 3:1 $=$ New Idria event, 2 = Coalinga event, and 3 = North : Kettleman Hills event. The axis of maximum compressive strain ( $\beta$ ) determined from triangulation and trilateration data is given along with the uncertainity in the direction.

Figure 5. Reference figure for the studies given in Table 4. B=Brush and $M=$ Mulligan are two stations in the USGS Pajaro Trilateration Network. $f$ and $g$ are sites at which geologically estimated rates of fault slip were determined for the San Gregorio and Hosgri faults (see $f$ and $g$ in Notes for Table 4). The line A-A' is that for which Namson and Davis, [1987] constructed their geologic cross section, see $i$ in Notes for Table 4. Faults are as given in Figure 1. FIN = Farallon Islands Network, $\mathrm{SBN}=$ San Benito Network, SLN = San Luis Network. VLBI stations: FTOR = Fort Ord, PRES = Presidio, PTRY = Point Reyes, and VNDN = Vandenberg. 
Table 1.Strain Rate Parameters for Spatial Subsets of the San Benito Network

\begin{tabular}{lcccccc}
\multicolumn{2}{l}{ Subnet Number of Angles } & $\begin{array}{c}\dot{\gamma}_{1} \\
\mu \mathrm{rad} / \mathrm{yr}\end{array}$ & $\begin{array}{c}\dot{\gamma}_{2} \\
\mu \mathrm{rad} / \mathrm{yr}\end{array}$ & $\begin{array}{c}\dot{\gamma} \\
\mu \mathrm{rad} / \mathrm{yr}\end{array}$ & $\beta$ & $\psi$ \\
\hline East & 14 & $0.18 \pm 0.11$ & $0.01 \pm 0.12$ & $0.18 \pm 0.10$ & $\mathrm{~N} 1^{\circ} \mathrm{W} \pm 20^{\circ}$ & $\mathrm{N} 46^{\circ} \mathrm{W} \pm 20^{\circ}$ \\
West & 9 & $0.07 \pm 0.14$ & $-0.18 \pm 0.13$ & $0.19 \pm 0.13$ & $\mathrm{~N} 34^{\circ} \mathrm{E} \pm 22^{\circ}$ & $\mathrm{N} 11^{\circ} \mathrm{W} \pm 22^{\circ}$ \\
North & 13 & $0.04 \pm 0.10$ & $-0.12 \pm 0.10$ & $0.16 \pm 0.11$ & $\mathrm{~N} 37^{\circ} \mathrm{E} \pm 20^{\circ}$ & $\mathrm{N} 8^{\circ} \mathrm{W} \pm 20^{\circ}$ \\
South & 7 & $0.22 \pm 0.16$ & $-0.13 \pm 0.22$ & $0.25 \pm 0.20$ & $\mathrm{~N} 10^{\circ} \mathrm{E} \pm 20^{\circ}$ & $\mathrm{N} 35^{\circ} \mathrm{W} \pm 20^{\circ}$ \\
$\begin{array}{l}\text { All stations } \\
\begin{array}{l}\text { except BIT,HEP, } \\
\text { and PAN }\end{array}\end{array} 25$ & $0.13 \pm 0.08$ & $-0.08 \pm 0.08$ & $0.15 \pm 0.08^{*} \mathrm{~N} 16^{\circ} \mathrm{E} \pm 14^{\circ} *$ & $\mathrm{~N} 29^{\circ} \mathrm{W} \pm 14^{\circ} *$
\end{tabular}

* These strain rate parameters have been scaled by the a posteriori variance factor [Vanicek and Krakiwsky, 1986]. 
Table 2.Fault-Slip Rates Inferred from Length Changes on Fault-Crossing Lines

Calaveras/Paicines Fault Zone

\begin{tabular}{lcccccc} 
Station 1 & \multicolumn{2}{l}{ Station 2} & No. of Obs. Period & $\begin{array}{c}\dot{i}, \\
\mathrm{~mm} / \mathrm{yr}\end{array}$ & $\begin{array}{c}\text { Azimuth, } \\
\operatorname{deg}\end{array}$ & $\begin{array}{c}\text { Slip Rate, } \\
\mathrm{mm} / \mathrm{yr}\end{array}$ \\
\hline BRN & CRS & 7 & $72.7-83.9$ & $-8.7 \pm 0.8$ & 168 & $9.9 \pm 0.9$ \\
CRS & CHL & 9 & $72.1-83.9$ & $-18.5 \pm 0.4$ & 181 & $24.9 \pm 0.5$ \\
BRN & CHL & 8 & $72.1-83.9$ & $27.4 \pm 0.4$ & 175 & $33.8 \pm 0.5$
\end{tabular}

Paicines Fault Adjacent to the Central Creeping Portion of the San Andreas Fault

\begin{tabular}{lccrrrrr} 
Station 1 & \multicolumn{2}{l}{ Station 2 } & No. of Obs. Period & \multicolumn{1}{c}{$\begin{array}{c}\dot{\mathrm{L}} \\
\mathrm{mm} / \mathrm{yr}\end{array}$} & $\begin{array}{c}\text { Azimuth, } \\
\mathrm{deg}\end{array}$ & $\begin{array}{c}\text { Slip Rate, } \\
\mathrm{mm} / \mathrm{yr}\end{array}$ \\
\hline BIT & HEP & 6 & $73.1-83.9$ & $3.7 \pm 0.5$ & 129 & $3.8 \pm 0.5$ \\
CHL & BIT & 8 & $72.1-83.9$ & $19.8 \pm 0.7$ & 280 & $25.8 \pm 0.9$ \\
CHL & HEP & 7 & $72.7-83.9$ & $27.4 \pm 0.6$ & 113 & $30.7 \pm 0.6$
\end{tabular}

$\dot{L}$ is the rate of line length change determined by least-squares, together with one standard deviation. Azimuth is measured clockwise from north. The slip rate is that appropriate to the strike-slip fault crossed by the indicated line.

The time period of observations are given in the decimal fraction of year. 
Table 3.Fault Slip Rates Indicated by Short-Range Trilateration Networks

\begin{tabular}{lccc} 
Network & No. of Obs. & Period & $\begin{array}{c}\text { Fault Slip } \\
\text { mm/yr }\end{array}$ \\
\hline Pionne & 8 & $75.2-87.3$ & $12 \pm 2$ \\
Dry Lake & 4 & $79.0-87.3$ & $27 \pm 2$ \\
Tully & 8 & $74.9-87.3$ & $32 \pm 1$
\end{tabular}


Table 4.Summary of Deformation Rates within the Central Coast Ranges

\begin{tabular}{|c|c|c|c|}
\hline Fault & Orientation & $\begin{array}{c}\text { Geological Slip Rate, } \\
\mathrm{mm} / \mathrm{yr}\end{array}$ & $\begin{array}{c}\text { Geodetic Slip Rate, } \\
\mathrm{mm} / \mathrm{yr}\end{array}$ \\
\hline \multicolumn{4}{|l|}{ Right-lateral strike-slip } \\
\hline Ortigalita & $\mathrm{N} 35^{\circ} \mathrm{W}$ & $0-2^{a}$ & \\
\hline San Andreas & $\mathrm{N} 41^{\circ} \mathrm{W}$ & $31-37 b$ & $32 \pm 3 c$ \\
\hline Rinconada & $\mathrm{N} 35^{\circ} \mathrm{W}$ & $0-2^{d}$ & $2 \pm 1 \mathrm{e}$ \\
\hline San Simeon & $\mathrm{N} 34^{\circ} \mathrm{W}$ & $6-9 f$ & \\
\hline San Gregorio & $\mathrm{N} 20^{\circ} \mathrm{W}$ & $7-11 g$ & $0 \pm 8^{h}$ \\
\hline \multicolumn{4}{|c|}{ Compression in the Coast Ranges } \\
\hline East of San Andreas & $\mathrm{N} 49^{\circ} \mathrm{E}$ & $2.2-5.5^{\mathrm{i}}$ & $\begin{array}{c}4.5 \pm 2.4 \mathrm{j} \\
\left(\mathrm{N} 16^{\circ} \mathrm{E}\right)\end{array}$ \\
\hline West of San Andreas & $\mathrm{N} 49^{\circ} \mathrm{E}$ & $4.4-11^{i}$ & $6.1 \pm 1.7 \mathrm{k}, 1$ \\
\hline
\end{tabular}




\section{Notes for Table 4}

a Hart et al. [1986].

b Sieh and Jahns [1984].

c This study; Savage and Burford [1973]; Thatcher [1979b]; Burford and Harsh [1980]; Lisowski and Prescott [1981].

d Hart et al. [1986]; D. B. Slemmons, personal communication, 1987; E. W. Hart, personal communication, 1988.

e This study. The line between Brush and Mulligan of the Pajaro trilateration network has been measured five times between May 1978 and April 1983. If we assume that the average line length change is due to right-lateral slip on the King City fault, a northern extension of the Rinconada fault, then a slip rate of $2 \pm 1 \mathrm{~mm} / \mathrm{yr}$ is indicated.

f Clark et al. [1985].

g Clark et al. [1985], two sites.

h On the basis of geodetic measurements made to the Farallon Islands between mid-1979 and late 1985[Prescott and $Y u, 1986]$.

i Namson and Davis [1987] obtained $11 \mathrm{~km}$ of shortening between the western Great Valley and the San Andreas fault. The $22 \mathrm{~km}$ of shortening to the west of the San Andreas fault was computed by deriving a solution that satisfies the observed structural relief. The ranges given for the rate estimates were calculated by assuming that shortening commenced between 5 m.y. and 2 m.y. ago.

j This study.

k Segall and Harris [1986]; Harris and Segall [1987]. Average rates of line length changes from the San Luis trilateration network were used to invert for slip rate at depth on the San Andreas fault. In order to fit the trilateration measurements from this network, it was necessary to include a component of contraction normal to the trend of the San Andreas fault. The inversion results suggest a spatially uniform normal strain of -0.06 
$\mu$ strain/yr. The net shortening rate across the network is $6.1 \pm 1.7 \mathrm{~mm} / \mathrm{yr}$. This estimated compression, however, may be due to a systematic bias in the older trilateration data [J.C. Savage, personal communication, 1987 ] .

12 Two additional geodetic studies using historical triangulation data have been made west of the San Andreas fault. Burford [1967] analyzed triangulation data measured between 1930 and 1951 from two networks. One extends from the region where the San Andreas and Calaveras faults diverge out to Monterey Bay and one extends from Kettleman Hills near Parkfield west to San Luis Obisbo. Outside a zone close to the San Andreas fault, the direction of maximum shortening was estimated to be approximately $\mathrm{N} 35^{\circ} \mathrm{E}$. As part of a general study of the deformation in central California Thatcher [1979b] examined triangulation data measured during the time interval 1944-1963 from the Salinias Valley network. Most of this network lies within the Salinian block located between the San Andreas and Rinconada faults. Examination of subregions suggest that the strains are poorly resolved with the orientation of the inferred strain field not correlated with any known faults or tectonic trends. Because of the uncertainities in the results, neither of these studies were used for rate determinations. 


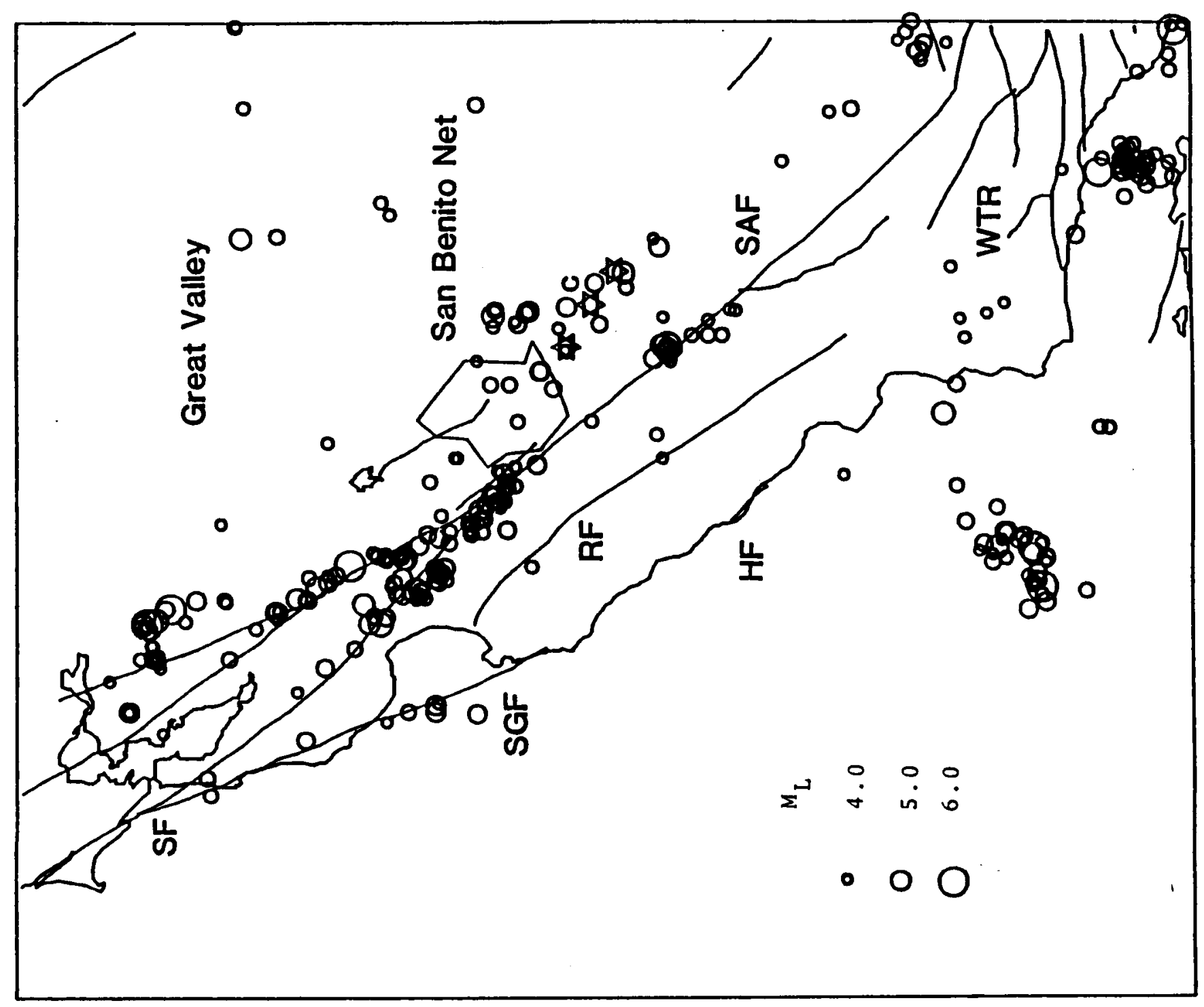




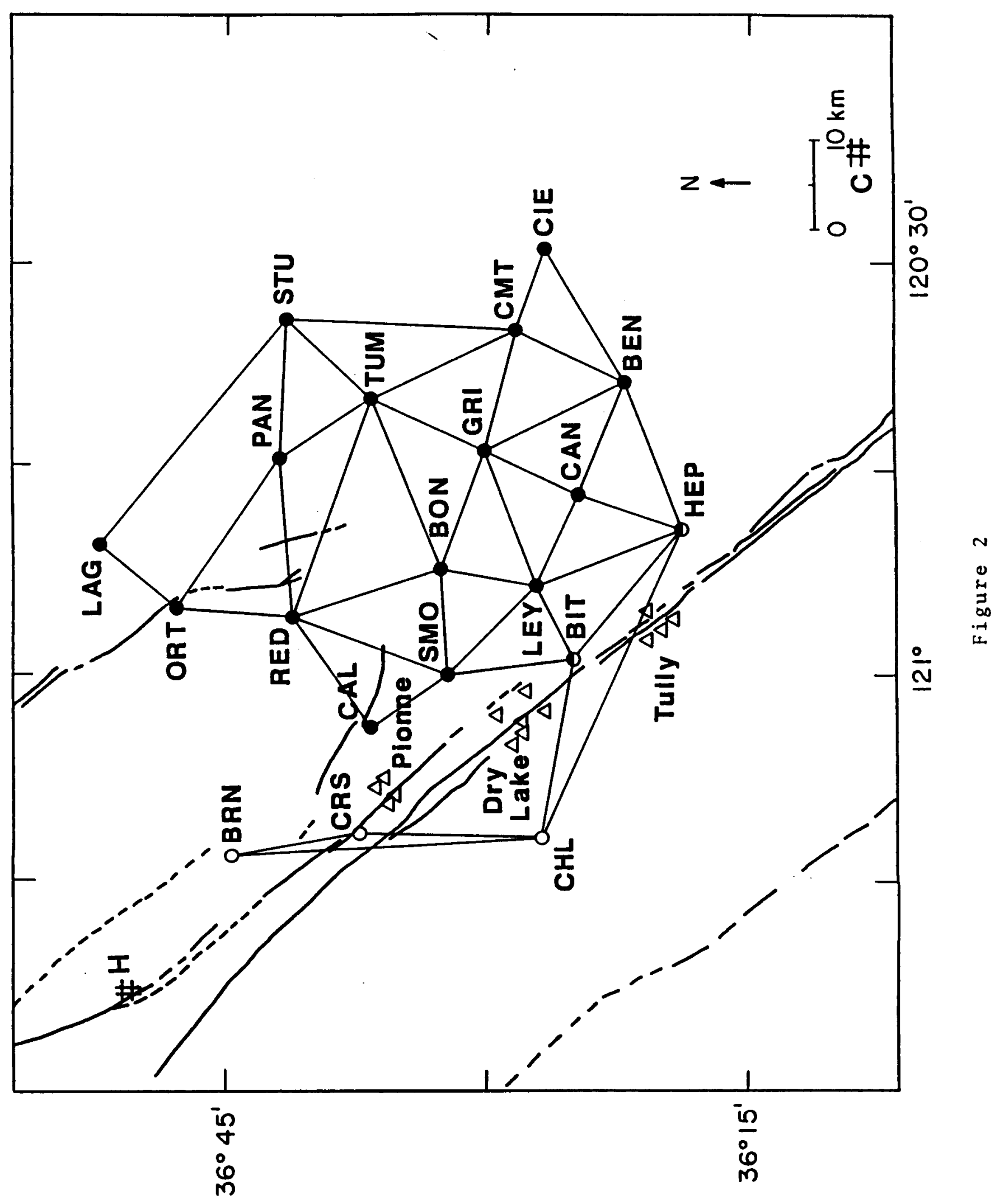




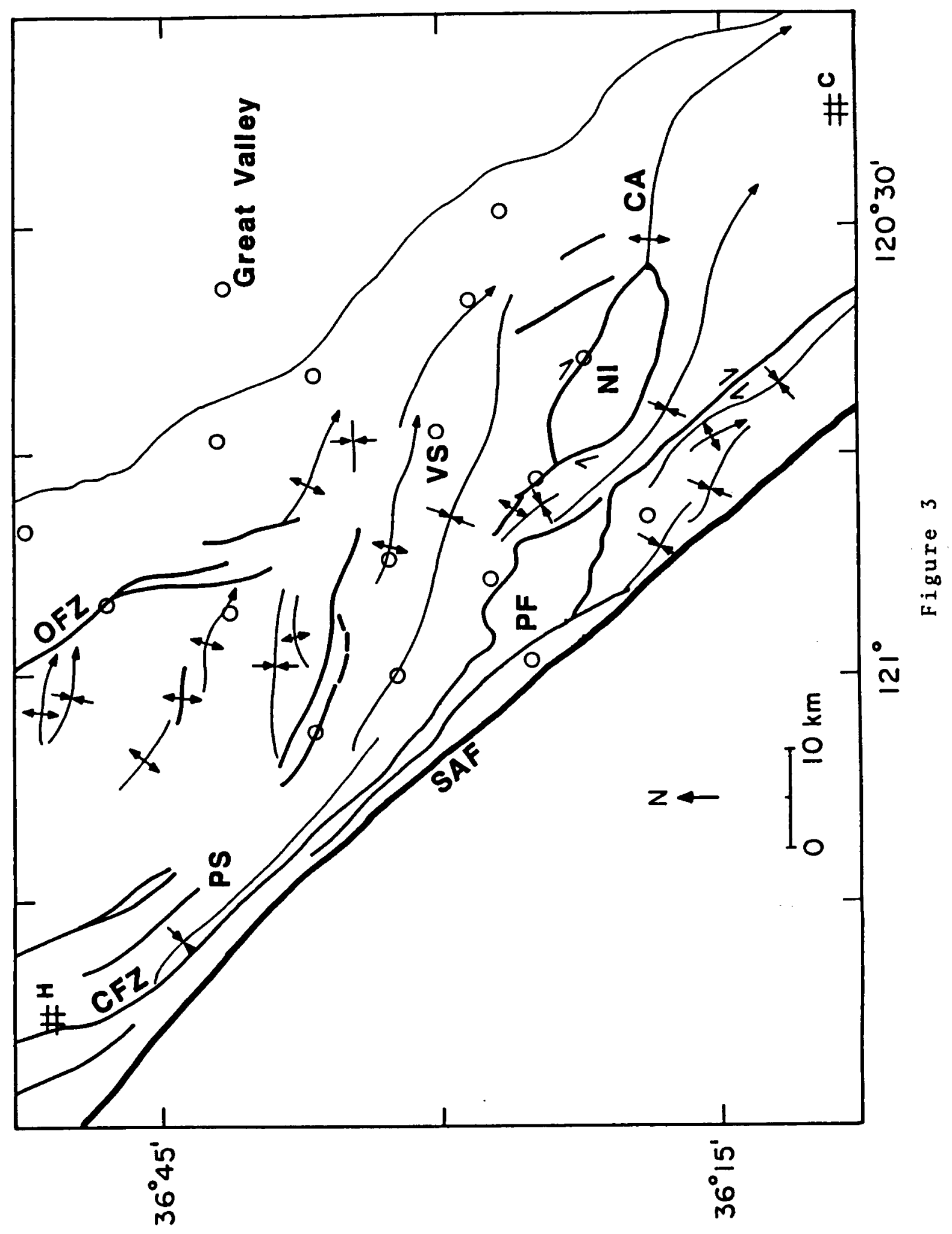




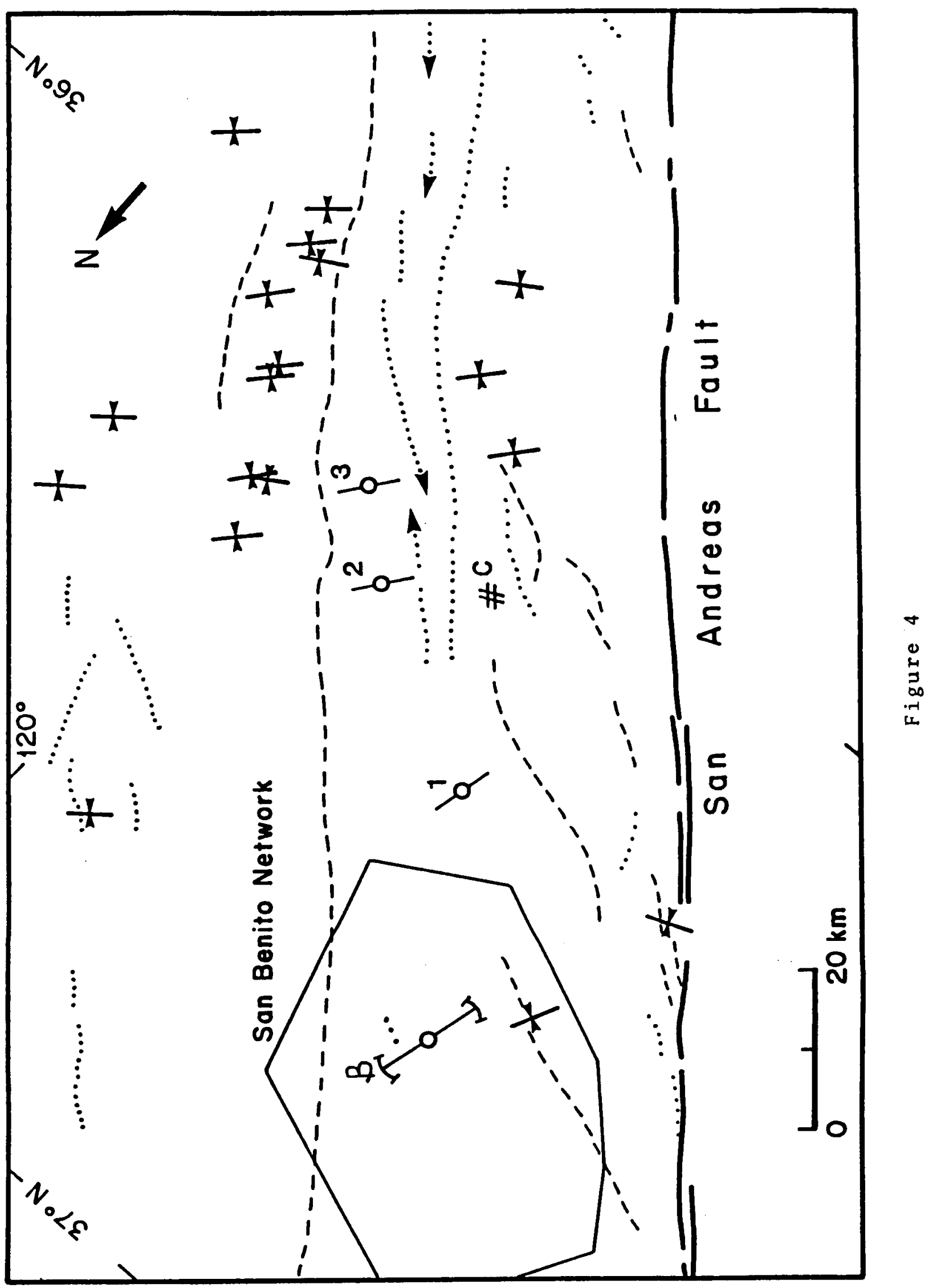


4

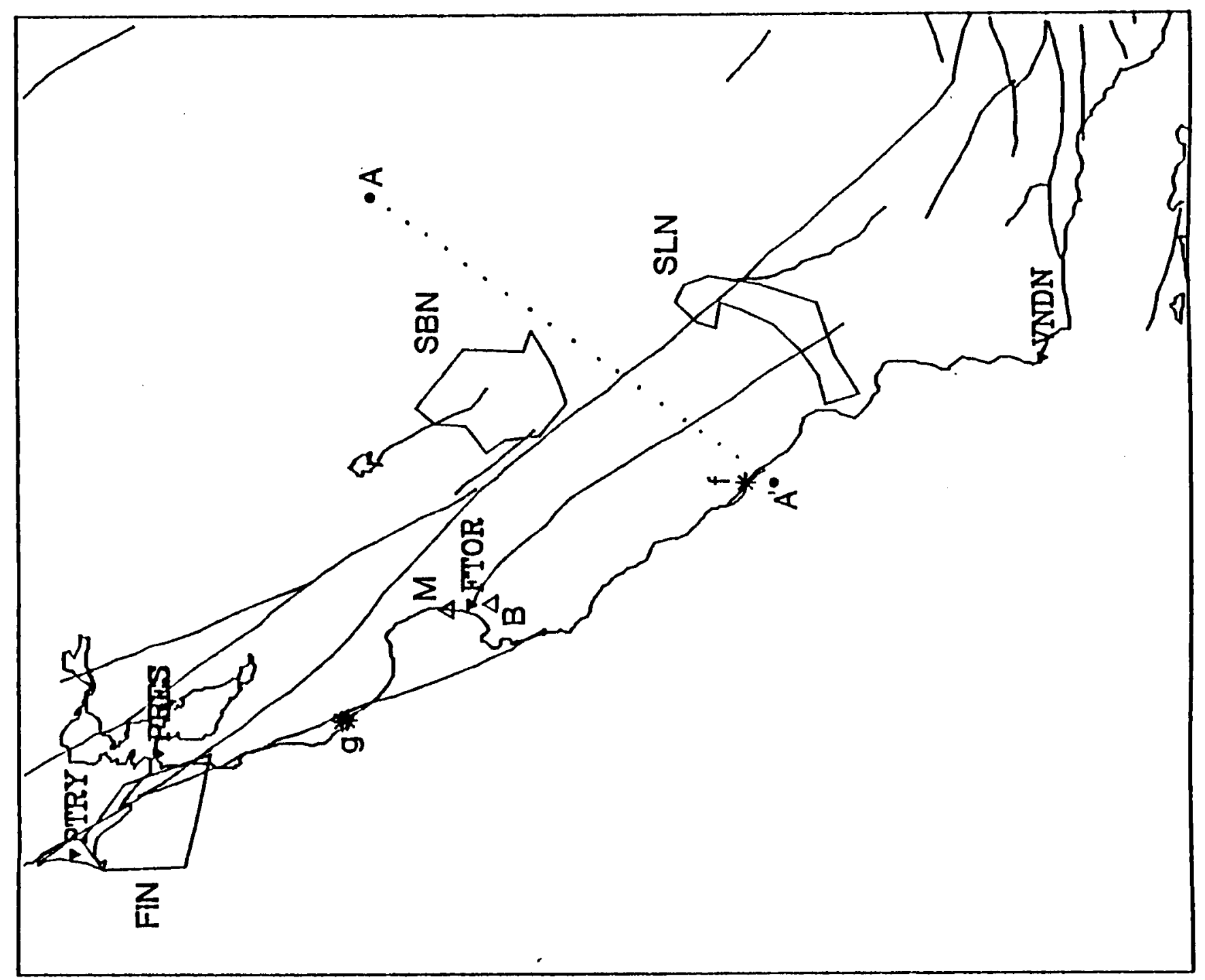

in
0
5
0
0
-1
-1
1 